\title{
Rastros de Deus segundo a íris riobaldiana em Grande Sertão: veredas
}

Hugo Fonseca

FERRAZ, S., et al.,orgs. Deuses em poéticas: estudos de literatura e teologia [online]. Belém: UEPA; Campina Grande: EDUEPB, 2008. 364 p. ISBN 978-85-7879-010-3. Available from SciELO Books $<\underline{\text { http://books.scielo.org }>\text {. }}$

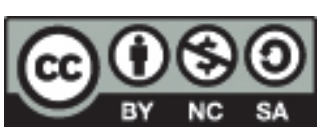

All the contents of this work, except where otherwise noted, is licensed under a Creative Commons Attribution-Non Commercial-ShareAlike 3.0 Unported.

Todo o conteúdo deste trabalho, exceto quando houver ressalva, é publicado sob a licença Creative Commons Atribuição Uso Não Comercial - Partilha nos Mesmos Termos 3.0 Não adaptada.

Todo el contenido de esta obra, excepto donde se indique lo contrario, está bajo licencia de la licencia Creative Commons Reconocimento-NoComercial-CompartirIgual 3.0 Unported. 


\title{
Rastros de Deus segundo a íris riobaldiana em Grande Sertão: veredas
}

\author{
Hugo Fonseca
}




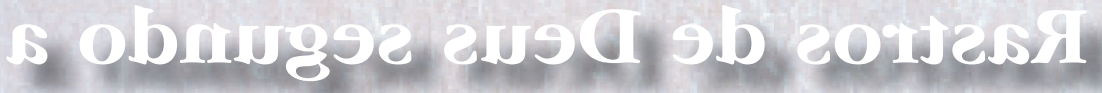

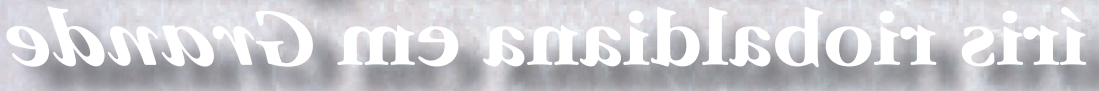
ablosisy a counse

Doganot OgNH 
FONSECA, Hugo*

Resumo: "Tudo é e não é". Analisar algumas imagens de Deus em Grande sertão: veredas é o objetivo deste artigo. Isso será feito numa tentativa de análise interdisciplinar. A partir do romance rosiano, sob a luz hermenêutica da critica literária e da reflexão teológica, tentaremos indicar que a literatura de Rosa apresenta Deus de modo ambíguo. Essa assertiva é possível, pois se percebeu na provisoriedade humana, advogada pelo escritor e expressa por Riobaldo, o núcleo de propagação desse modo de ver. Ao rememorar e ressignificar sua vida, Riobaldo abre espaço ao Mistério. Em cada travessia reflete sobre o mesmo sem enquadramentos teológicos e filosóficos definitivos. O "Deus que roda tudo" está misturado no mundo e só pode ser percebido pelo seu constante movimento entre o obscuro e o revelado. Com isso, o texto rosiano apresenta imagens de Deus que salvaguardam seu caráter duplo e ambíguo.

Palavras-chave: Ambigüidade, Imagem, Deus, Diabo, Linguagem.

Abstract: "Everything is and it is not". The paper's goal is to analyze some images of God in Grande sertão: veredas by means of an interdisciplinary analysis. Starting from the Rosean novel, under the hermeneutic light of literary criticism and theological reflection, the paper suggests that the Rosa's literature presents God in an ambiguous way. The statement is possible the provisional nature of the human, advocated by the writer and expressed by Riobaldo constitutes the nucleus from which this point of view is disseminated. By remembering and re-signifying his life, Riobaldo gives way to Mystery. In each crossing, he rethinks Mystery without resorting to any definitive theological and philosophical frame. The "God that turns everything" is mixed in the world and only can be noticed by his constant movement between the obscure and the revealed. Thus, the Rosean text presents images of God that preserve his double and ambiguous character.

Keywords: Ambiguity, Image, God, Devil, Language.

* Professor-tutor da Faculdade de Teologia na Universidade Metodista de São Paulo (UMESP). Mestrando em Ciências da Religião nesta Universidade, onde desenvolve pesquisa em Teologia, Religião e Literatura. E-mail: hugo.junior@metodista.br. 


\section{Introdução}

Escreverei, fundamentalmente, do que me foi falado por Riobaldo. Uma vez que é na anamnesis riobaldiana que encontrei a pista para o diálogo entre teologia e literatura. O que se pretende para esse momento é apresentar algumas imagens de Deus no romance rosiano e analisá-las, considerando o caráter ambíguo da linguagem teológico-literária. Galvão, em seu estudo sobre as ambigüidades em Grande Sertão: Veredas, aponta esta característica da linguagem do seguinte modo:

Se, por um lado, o falar sertanejo permite e justifica que o livro se arme como uma discussão metafísica sobre Deus e o Diabo, aceita-se essa discussão porque esses são conceitos que estão ao alcance do narrador-personagem para efetuar a tentativa de demarcar os limites entre a liberdade humana e a necessidade imposta pelo sistema de dominação. Mas, por outro lado, o contingente erudito da linguagem usada pelo escritor permite e justifica que Deus e o Diabo sejam, ao fim e a cabo, concepções muitos mais requintadas e que derivam tanto de Heráclito como do budismo. (GALVÃO, 1986. p. 74).

A concepção de Galvão indica "ao fim e a cabo" Deus e o Diabo como figuras "mais requintadas na fala de Heráclito e do budismo". Isto atribui um valor superior às idéias de Deus e do Diabo em tais perspectivas e, de certo modo, valora a influência erudita em detrimento da rica influência sertaneja.

Apesar de discordar da concepção de Galvão que indica "ao fim e a cabo" Deus e o Diabo como figuras "mais requintadas na fala de Heráclito e do budismo". O que atribui um valor superior às idéias de Deus e do Diabo em tais perspectivas e, de certo modo, valora a influência erudita em detrimento da rica influência sertaneja. Galvão nos permite entrever que, na construção da obra rosiana, a imagem de Deus está em relação dialógica com a imagem do Diabo e que ambas as imagens são perpassadas pelo duplo enriquecimento do erudito e do 
popular. É a partir destas pistas, observadas nas próprias "aparições" de Deus e do Diabo, que a análise teológico-literária se construiu. Pode-se afirmar ainda que o romance rosiano é aquele quem pavimenta o diálogo entre teologia e literatura, o qual se delineia como ato de indicação e suspeita, não de determinação e encerramento. Riobaldo ratifica essa maneira de interpretar com as seguintes palavras:

Eu sei que isto estou dizendo é dificultoso, muito entrançado. Mas o senhor vai avante. Invejo é a instrução que o senhor tem. Eu queria decifrar as coisas que são importantes. E estou contando não é uma vida de sertanejo, seja se for jagunço, mas a matéria vertente. (...) Assim, é como conto. Antes conto as coisas que formaram passado para mim com mais pertença. Vou lhe falar. Lhe falo do sertão. Do que não sei. Um grande sertão! Não sei. Ninguém ainda não sabe. (ROSA, 2001. p. 116) ${ }^{146}$

Ao falar da matéria vertente e do que não sabe, Guimarães Rosa, por meio do eu-lírico, arvora-se para o plano existencial, simbólico e religioso. A travessia iniciada pelo protagonista-narrador é expressa por meio de uma linguagem que flerta constantemente com a oralidade sertaneja e é construída sob a égide da poesia. Tal linguagem está ambientada num grande sertão, do qual se sabe pouco, por conta de sua característica universal. É neste espaço ao mesmo tempo diverso e singular que se nos apresentam as imagens de Deus.

Destarte, pontuamos quatro momentos da análise para nossa reflexão: a) seleção e apresentação de textos carregados de imagens de Deus; b) análise destas imagens com o auxílio do próprio autor, da crítica literária e da reflexão teológica; c) análise do processo de rememoração; d) análise da linguagem rosiana.

146 Essa citação antecede o início do relato sobre a experiência que teve ao encontrar Reinaldo-Diadorim-Deodorina e com esta (ou este) experimentar a travessia do São Francisco. Rio que, como ele mesmo diz, partiu sua vida em duas partes. 


\section{O Deus rosiano e o espelho do Demo: pressupostos} da leitura

Todos os meus livros são simples tentativas de rodear e devassar um pouquinho o mistério cósmico, esta coisa movente impossível, perturbante, rebelde a qualquer lógica, que é chamada 'realidade', que é a gente mesmo, o mundo, a vida. Antes o obscuro que o óbvio, que o frouxo. Toda lógica contém inevitável dose de mistificação. Toda mistificação contém boa dose de verdade. (BUSSOLOTTI, 2003. p. 238)

A confissão de Rosa somada às contribuições da análise teológico-literária - especialmente J. Miles e A. Magalhães ${ }^{147}$ - e da proposta da linguagem teológico-analógica constituem a maior pista para a proposta hermenêutica que elegi como mais adequada ao diálogo entre teologia e literatura, tendo em vista o "Deus Rosiano". Se "a mistura, as oscilações, as impurezas e as ambigüidades da vivência assim como do relato, do próprio ato de narrar, inquietam Riobaldo" (ROSENFIELD, 1992. p. 16), a mim são, igualmente, porquês de inquietação. Seguir os rastros de Deus, ou melhor, o roteiro de Deus em Grande Sertão: Veredas é deparar-se com um "obscuro" de imagens narradas, ou melhor, rememoradas por Riobaldo. É válido lembrar que este não quis responder à cogitatio Dei com sim ou não, com ser ou não ser. Riobaldo, pela pena de Rosa, opta pela ambigüidade, ou seja, pelo ser e não ser, presente na sentença, indicadora de seu pensamento e interpretação: "Eu penso é assim, na paridade. (...) Viver é muito perigoso; é não é não. (ROSA, 2001. 328).

Essa frase é, a meu ver, o emblema da escritura rosiana, mas não como uma solução que encerra, antes sim, como uma proposição, ou ainda, como uma indicação. Desta forma, antecipamos uma questão inevitável: Em havendo "paridade", qual seria o par de Deus?

Rosa nos responde com o subtítulo do romance, "o diabo na rua no meio, do redemoinho...”. Deus e Diabo estão em relação, todavia não numa relação de exclusão ou comparação, mas sim de dupla-pertença, percebida num espelho que não só reflete, mas também transverbera

147 MAGALHÃES, Antonio. Deus no Espelbo das Palavras: Teologia e Literatura em diálogo. São Paulo: Paulinas, 2000, 216 p. Série: Literatura e Religião \& MILES, Jack. Deus: uma biografia. Trad. José Rubens Siqueira. São Paulo: Companhia das Letras, 1997, 497 p. 
(RIVEIRA, 2005. p. 25) ${ }^{148}$. Transverberar é entendido como ato de fazer transparecer, o qual proporciona ver em cada imagem o que está oculto e o que está revelado. O movimento deflagrador da ambigüidade, movimento realizado por Riobaldo - sujeito muito "provisório" - apresenta Deus no espelho do Demo e vice-versa. Com essa forma de pensar concorda Magalhães, cuja opinião é que: “(...) bem e mal se tocam, não são excludentes sempre, não se mostram de forma antagônica, não se reduzem à interpretação maniqueísta." (MAGALHÃES, 2003. p. 91).

Essa realidade - aquela de Rosa, rebelde a qualquer lógica - funda, na verdade, um modo de ver, de refletir e de interpretar o "Deus rosiano", por meio da íris riobaldiana. Esse exercício, como pode parecer, não é um emaranhado filosófico ou teológico de especulações sobre Deus. Neste erro pode-se incorrer facilmente, principalmente quando, ao reconhecermos a ambigüidade, encontramos o suposto fim da tarefa hermenêutica. Para evitar esse perigo, observaram-se dois parâmetros: a) as pistas valorativas do próprio autor (literárias), que, apesar de não serem definitivas, tentam ser inteligíveis; b) as pistas valorativas da fé cristã (teológicas) que, apesar de, em muitos casos, apresentaram-se definitivas, buscam salvaguardar a palavra última ao Sagrado e ao Mistério.

Rosenfield, de modo arguto, concebe a necessidade de indicar os traços da ambigüidade presente no romance rosiano como desdobramento do caminho narrativo que o escritor adotou. Desta feita, além da ambigüidade unificar o estilo literário do autor, ela é aquela que demonstra as demandas existenciais das personagens e, por conseguinte, o caminho interpretativo das mesmas. Assim ela nos indica:

$\mathrm{O}$ alto e o baixo, o claro e o escuro, o passageiro e o durável não são apenas especificações físicas, mas nelas expressam-se valores éticos da comunidade. (...) há maneiras de contar que determinam tão imperiosamente nossa imaginação que se torna difícil escutar, ler e mesmo perceber fora dos seus moldes. (ROSENFIELD, 1992. pp. 17 e 18)

Essa dificuldade em apontar diferenças entre a imagem de Deus e a imagem do Diabo, a despeito das contigüidades destes, constituiuse como desafio que moveu a reflexão deste texto. Não se pretende 148 Aqui me refiro estritamente à contribuição de Rivera, que compreende esta palavra como reverberação transposta, transformada. A autora, ao analisar o conto "O espelho", identifica esta expressão - sinalizadora da técnica de Rosa - como meio necessário para se transitar do outro ao um ou, em nosso caso, de Deus ao "Demo". 
estabelecer uma análise sobre os valores e atributos exclusivos de Deus e do Diabo, para, a partir disso, identificá-lo, depurá-los e defini-los; esse artigo segue outra orientação hermenêutica. O que se pretende foi indicar que a ambigüidade presente no método escriturístico de Rosa e na rememoração-narrativa do seu eu-lírico está presente no cerne da linguagem literária e da linguagem teológica. A despeito da tradição dogmática de perfil eclesiástico cristão anunciar um Deus imutável e eterno (fora do tempo), o romance rosiano fala de um Deus mutável e "que se economiza", um Deus que é e não é. Mais espelhado no Javé veterotestamentário (consultar o texto de Jack Miles, Deus: Uma biografia). No quadro desta pretensão, procuro seguir o roteiro de Deus acompanhado de Riobaldo, que vivenciou esse dilema, exprimindo-o nos seguintes termos:

Baixei, mas fui ponteando opostos. Que isso foi o que sempre me invocou, o senhor sabe: eu careço de que o bom seja bom e o rúim ruím, que dum lado esteja o preto e do outro o branco, que o feio fique bem apartado do bonito e a alegria longe da tristeza! Quero todos pastos demarcados... Como é que posso com este mundo? A vida é ingrata no macio de si; mas transtraz a esperança mesmo no meio do fel do desespero. Ao que, este mundo é muito misturado... (ROSA, 2001. p. 237)

\section{Deus esteja: Aparições e rastros do Deus rosiano}

- Nonada. Tiros que o senhor ouviu foram de briga de homem não. Deus esteja. (ROSA, 2001. p. 23)

Assim começa o romance de Rosa. Ao início cabe o mistério, cabe o nada da origem, o nada que-dizer sobre a fundação e seu provável Fundador. A palavra "nonada", cunhada pelo autor, é indicativa do que está por vir, é o prenúncio de todo o romance (MARTINS, 2001. p. 310). Além disso, "nonada" executa uma função descortinadora, uma vez que "no-nada" se desenrolará uma estória sobre o que é particular e universal, sobre o que é imanente e transcendente. Para trilhar esse caminho (as veredas do Grande Sertão) só com Deus, o personagem presente no nada original, conforme alude a tradição judaico-cristã. É como se Riobaldo nos dissesse: "Neste nada, quero que Deus esteja".

"Nonada" também pode indicar um simples "não é nada (no nada)". Desta interpretação precipita-se a pergunta: Ao que se refere 
esse "nada"?

Refere-se aos tiros que deram em um bezerro, branco, cara de cachorro, cara de gente, segundo os que atiraram, "era o demo". O Demo "no-nada" ou, em outras palavras, "o demo não é nada, Deus esteja". O Diabo como nada e o Deus como esteja (presença) representam um dos núcleos das discussões metafísicas do autor.

O Deus que está no nada é o Deus que está por toda parte, uma vez que participa do todo que antecede, da raiz de toda existência. Seguindo a narrativa de abertura do texto, Riobaldo nos conta sobre o espaço, no qual se desenvolve essa trama:

O senhor tolere, isto é o sertão. Uns querem que não seja: que situado sertão é por os camposgerais a fora a dentro, eles dizem, fim de rumo, terras altas, demais do Urucúia. (...) Lugar sertão se divulga: é onde criminoso vive seu cristo-jesus, arredado do arrocho de autoridade. (...) O gerais corre em volta. Esses gerais são sem tamanho. (...) O sertão está em toda parte. (ROSA, 2001. pp. 23 e 24)

O sertão é o espaço de realização do mítico, do transcendental. Atemporal (lugar do sertão se divulga) e imensurável (esses gerais sem tamanho), o sertão é o perfeito locus do duplo - "tudo incerto, tudo certo" (ROSA, 2001. p.172) -, o espaço de Deus, que, por sua vez, em toda parte está. Assim analisa Galvão ao se referir ao tal espaço:

(...) encontramos um sertão mítico, onde em jogo está a salvação ou a perdição do ser humano, mero peão na eterna batalha entre Deus e o Diabo. (...) Um espaço onde o maravilhoso e o fantástico fazem parte da vida cotidiana. (GALVÃO, 2000. p. 30, negrito nosso)

O espaço marcado pela ambigüidade conjuga dois personagens de modo ímpar: o Deus, que Riobaldo quer que esteja, e o Diabo, que está no meio da rua. Sobre o Diabo Riobaldo lança uma sentença, não a fim de determinar, antes sim para refletir no espelho de Deus. Assim afirma:

(...) o diabo vige dentro do homem, os crespos do homem - ou é o homem arruinado, ou o homem dos avessos. Solto, por si, cidadão, é que não tem diabo nenhum. (ROSA. 2001. p. 26, ne- 


\section{grito nosso)}

No extenso estudo de Heloísa Vilhena, o Diabo representa "a traição do melhor do que o ser humano é capaz", ou seja, a falha, a humanidade caída e eivada de potência (ARAUJO, 1996. p. 27). Vilhena faz a ligação da concepção de Diabo como a encarnação do mal. Essa ponte tem como pavimento a idéia de inferno em Dante, que apresenta como essência a própria traição (ARAUJO, 1996. pp. 24 e 25). O Diabo como mal, segundo a autora, não existe, ou melhor, é um nãoente, que só pode ser em desdobramento da condição de traição, que o próprio humano executa. Com isso, podemos entrever uma possibilidade de Diabo (para Rosa) e mal (para Vilhena) como o que habita o humano, sendo perceptível somente "pelo humano dos avessos", ou seja, o desconhecido e o oculto presentes no caráter humano. Segundo Riobaldo:

Tem diabo nenhum. Nem espírito. Nunca vi. Alguém devia de ver, então era eu, eu mesmo, este vosso servidor. (...) Bem, o diabo regula seu estado preto, nas criaturas, nas mulheres, nos homens. (ROSA, 2001. p. 26, negrito nosso)

Portanto, o Diabo está no "preto das coisas", no obscuro, o desconhecido que se quer saber, mas não se acha. Seguindo suas reflexões sobre o Diabo, aparece pela primeira vez no texto o dito emblemático de suas elucubrações: "É, e não é. O senhor ache e não ache. Tudo é e não é..." (ROSA, 2001. p. 27). Aqui nós temos uma pista que evita trilhar o caminho da comparação classificatória, ou melhor, da ambigüidade que classifica Deus como um não-Diabo ou este como um não-Aquele. É como se Rosa apontasse ao Diabo para falar do homem, em outras palavras, o que ao Diabo pertence, se circunscreve nos horizontes do "homem humano a caminho", a fim de deixar Riobaldo explicar, lemos:

Amável o senhor me ouviu, minha idéia confirmou: que o Diabo não existe. Pois não? (...) Nonada. O diabo não há! É o que eu digo, se for... Existe é homem humano. Travessia. $\infty$ (ROSA, 2001. p. 624)

O "homem humano, na travessia", apesar de apresentar o dado obscuro que todo viator ${ }^{149}$ experimenta e de desconhecer o que sua 149 Pseudônimo utilizado por Rosa, quando este concorreu ao prêmio do Concurso Humberto de Campos de literatura, da livraria José Olympio, com um livro intitulado Contos, em 1938. 
caminhada revelará - neste desconhecimento/ignorância descobre o que "vige em seus crespos", o Diabo -, aponta para um alvo, um porto a buscar, um ad infinitum ${ }^{150}$. Isto se identifica na última pista que Rosa nos deixa, a saber, o símbolo matemático do infinito $(\infty)$. Com isso, ao apontar um para-além/ad infinitum, Riobaldo nos aponta para um caminho, um método, que tem na travessia - reveladora dos desconhecimentos do "homem humano" - a via de interpretação sobre Deus. A esta pista hermenêutica soma-se a seguinte reflexão de Magalhães:

Em Grande Sertão: Veredas a questão do mal deve ser encarada como forma de ser o próprio rosto de Deus, mas também como desvelamento das potencialidades destrutivas da vida humana (o obscuro). Isto dá ao tema (bem e mal) a dimensão de complementaridade e revelação. No mal percebemos níveis profundos da vida e dos caminhos que trilhamos para construí-la. (MAGALHÃES, 2003. p. 94)

No caminho ao nada que dá sentido ou ao nada original (nonada), Riobaldo exercita sua fé contra a insanidade do não-sentido. Ao afirmar que "reza é que sara loucura" (ROSA, 2001. p. 32), Riobaldo anuncia sua busca pelo sentido da vida. Esse sentido ele encontra na rememoração e na religião, ou melhor, na reflexão do vivido - que clareia o que está obscuro - e na prática de fé - que o religa com Deus. Nesse aspecto, entende-se o Diabo, circunscrito ao humano, como o daimôn socrático, figura ambígua portadora do diabólico e do divino. Espécie ente que "vige no homem arruinado" e leva-o a conhecer-se ainda melhor, guia-o tanto ad intra quanto ad extra, fala ao íntimo sem perder de vista o Norte da travessia. $\mathrm{O}$ daimôn como realidade divina, também presente no romance rosiano, traz luz ao que antes estava obscuro, impulsiona Riobaldo-viator à força vital que conduz o "homem huma-

150 Como toda época da história da teologia é marcada por temas que matizam as correntes teológicas, as diferentes áreas teológicas expressam as grandes questões hermenêuticas de seu tempo, corroborando definitivamente para seu caráter dialógico e plural. Deste modo, a teologia é ad intra, em seu movimento avaliativo, ad extra, em seu caráter profético, e ad infinitum, em sua esperança escatológica. Tais movimentos são correlacionáveis, uma vez que matizam os vieses de um mesmo caminho - o teológico - e constituem esse percurso como saber que se diversifica em várias maneiras, correntes e perspectivas de realização da única e multiforme inteligência da fé. Aqui, ao perceber o humano rosiano a caminho ad infinitum, vislumbro a proximidade da reflexão literário-antropológica de Rosa com o movimento hermenêutico-antropológico da Teologia. (MANZATTO, Antonio. Teologia e Literatura, p. 45). 
no", constituindo-se como fonte de energia e criatividade, sem perder o traço duplo (MAGALHÃES, 2003. p. 95 \& ARAUJO, 1996. pp. 54 e 55). Tal traço se percebe in via, num caminho onde a percepção demanda a hermenêutica que, por sua vez, verbaliza o interpretado em imagem perceptível (numa espécie de movimento piramidal). Com a ajuda de Riobaldo, conseguiremos compreender esse círculo de maneira mais clara:

Deus não queira; Deus roda tudo! (...) quem-sabe, a gente criatura ainda é tão ruim, tão, que Deus só pode às vezes manobrar com os homens é mandando por intermédio do diá? Ou que Deus - quando o projeto que ele começa é para muito adiante (ad infinitum), a ruindade nativa do homem só é capaz de ver o aproximo de Deus é em figura do Outro? (ROSA, 2001. p. 56, negrito nosso)

O Deus que faz a "roda da fortuna" girar não se apresenta de maneira monótona, a imago Dei é perceptível no diá, um prefixo igualmente ambíguo, uma vez que pode significar Diabo - trevas - e Deus - luz (ARAUJO, 1996. pp. 48-52 \& MACHADO, 1991. pp. 38-43). Isso demonstra que o projeto "para muito adiante", aqui interpretado como ad infinitum, não pode eximir-se da cultura da ambigüidade, pois é a linguagem rememorativa do ex-jagunço-fazendeiro que ressignifica a vida, torna história em estória, ao contar sobre as veredas que cruzou.

Este homem "muito provisório" reconhece a dificuldade em definir um objetivo, uma imagem determinada, quando se caminha para além entre as "manobras do Deo e do Dia". Com isso, interpreta-se o protagonista-narrador como um sujeito que se reconstrói na tentativa de se desprender da imagem atual (ex-jagunço-fazendeiro), para se ver alternadamente como eu e outro (como sujeito ambíguo) na imagem (Deo e Dia) que lhe funda o processo narrativo, a saber, o "nonada" onde Deus e Diabo são matéria vertente. O que desvela um movimento de "trans-parecimento", o qual não se subtrai no aparecimento do outro (o Riobaldo da rememoração) e nem se estanca no desaparecimento do eu (o Riobaldo-velho rememorador) ${ }^{151}$. Este, ao recontar a vida, reconhece o dilema apresentado acima da seguinte maneira:

Então, eu era diferente de todos ali? Era. (...) E

151 Direta foi a influência das contribuições de Rivera à maturação da reflexão que se apresentou acima. Com mais detalhes ver: RIVERA, Tânia. Guimarães Rosa e a Psicanálise: Ensaios sobre imagem e escrita, p. 22. 
eu era igual àqueles homens? Era. (...) Afirmo ao senhor, do que vivi: o mais difícil não é um ser bom e proceder honesto; o dificultoso, mesmo, é um saber definido o que quer, e ter o poder de ir até o rabo da palavra. (ROSA, 2001. pp. 188 e 189, negrito nosso)

Talvez aqui tenhamos o motivo de tantas idas e vindas no narrar, de tantos ditos sobre Deus e o Diabo. Riobaldo não sucumbe aos conhecimentos determinados, ao saber do interlocutor douto, ele mesmo vasculha o que desconhece, "desconfiando de muita coisa, divergindo de todo mundo” (ROSA, 2001. p. 31). É ele o caminhante (ou seria cambiante?), o viator, a quem basta a travessia, a palavra e a fé. Desta maneira, pontua seu saber num caminho paradoxal, onde:

Deus é paciência. O contrário, é o diabo. (...) Deus não se comparece como refe ${ }^{152}$, não arrocha o regulamento. Para que? Deixa: bobo com bobo - um dia, algum estala e aprende: esperta. Só que, às vezes, por mais auxiliar, Deus espalha, no meio, um pingado de pimenta... (ROSA, 2001. p. 33)

A imago Dei, em Riobaldo, é não só um alvo, um ad infinitum, mas também o próprio caminhar no sertão. Uma travessia que explica sua vida em constante mudança, em muitos momentos tais mudanças são atribuídas a Deus, Aquele que espalha, ou melhor, que torna a vida alterada no meio da travessia (Vida tornada alter, do latim outro. RIVEIRA, 2005. p. 24) Essas transformações atingem o sujeito por completo, modificam seu modus vivendi, conseqüentemente, seu modus cogitandi ou como-ver (ou ainda método hermenêutico) o todo, inclusive o como-ver Deus. Sobre a provisoriedade humana e a decisiva mudança interpretativa em relação a tudo que ocupa sua vida, Riobaldo afirma:

O senhor... Mire e veja: o mais importante e bonito, do mundo, é isto: que as pessoas não estão sempre iguais, ainda não foram terminadas - mas que elas vão sempre mudando. Afinam ou desafinam. Verdade maior. É o que a vida me ensinou. (...) o diabo é as brutas; mas Deus é traiçoeiro! Ah, uma beleza de traiçoeiro - dá gosto! A força dele quando quer - moço! - me dá o medo pavor! Deus vem vindo: ninguém não vê. Ele

152 Refe significa espingarda curta, rifle. 
faz é assim, na lei do mansinho - assim é o milagre. E Deus ataca bonito, se divertindo, se economiza. (ROSA, 2003. p. 39, negrito nosso)

Ao que é provisório e às mudanças, Riobaldo parece apontar um caminho/método duplo. Um roteiro onde dois elementos recortam o viver humano. Um desses elementos é o da mudança drástica, que agride com estranheza a vida humana, ou seja, o abrupto tem seu lugar na necessidade de alteração da vida, um elemento forçoso - é o "as brutas". Outro elemento é o da mudança sem "arroucho de regulamento", aquele da "lei do mansinho", quase imperceptível - é a paciência. Aqui tem seu espaço o mistério do milagre, a mudança que não apaga o sujeito, apesar de transformá-lo (MAGALHÃES, 2003. pp. 93 e 94).

\section{Deus in via: Rememoração da íris riobaldiana como processo fundador de imagens ambígüas}

Neste caminho de mudanças admitidas pelo narrar, Riobaldo nos diz o porquê da opção pela travessia de rememorações e ambigüidades, travessia esta que não tem o cronológico como dado a priori, antes sim como mais um elemento constitutivo do objetivo mais importante, a saber, o sentido da vida:

A lembrança da vida da gente se guarda em trechos diversos, cada um com seu signo, e sentimento, uns com os outros acho que nem não misturam. Contar seguido, alinhavado, só mesmo sendo as coisas de rasa importância. De cada vivimento que eu real tive, de alegria forte ou pesar, cada vez daquela hoje vejo que eu era como se fosse diferente pessoa. (...) Tem horas antigas que ficaram muito mais perto da gente do que outras de recente data. (ROSA, 2001. pp. 114 e 115)

É diante da possibilidade do duplo-ser ou do ser-alterado, apresentada pela narrativa de rememoração, que Riobaldo enxerga e interpreta Deus. Desta perspectiva surge o "Deus rosiano". Sua origem, portanto, está atrelada à palavra, àquela recontada pelo sujeito provisório em perene mudança. Deste modo, o "Deus rosiano" permanece in via com Riobaldo, quebrando o tempo entre o cronológico - o tempo alinhavado das horas - e o kairológico - o tempo providencial do "mi- 
lagre" -, surge como imagem por meio da palavra.

No ato de palavrear, o protagonista-narrador identifica o locus da origem, uma vez que a palavra irrompe no-nada, a fim de se tornar movente e em rumo, ou melhor, de permanecer a caminho. Antes de outras meditações sobre o que esse caminho nos ensina, ouçamos Riobaldo:

O que eu vi, sempre, é que toda a ação principia mesmo é por uma palavra pensada. Palavra pegante, dada ou guardada, que vai rompendo rumo. (ROSA, 2001. p. 194)

Ao observarmos a aproximação entre texto literário, análise literária e reflexão teológica, precisamos entender que o teologizar não é, em última análise, um conjunto de doutrinas e dogmas eclesiásticos, mas, sobretudo, é a expressão hermenêutica acerca do Sagrado na cultura movente da humanidade. Como campo de expressão, a teologia manifesta-se por meio da linguagem que lhe é peculiar, a saber, a linguagem analógico-metafórica. Com isso, compreendemos a linguagem teológica como linguagem das tentativas, aquela que responde com o sim e com o não, e, por conta disso, torna-se locus por excelência da interface pesquisada. ${ }^{153}$

Lembrando dos escritos bíblicos de tradição judaico-cristã, em algum tempo na origem (in illo tempore), a Palavra de Deus (Logos de Deus) funda o cosmos (o todo vivo) por meio da palavra, precisamente, por meio da nomeação. Do nada irrompe a palavra fundante: $\mathrm{E}$ disse Deus (Gênesis 1, 3-26). Essa palavra em ação é o pilar mais contundente do que-dizer teológico. A palavra "rompendo em rumo, principia mesmo toda ação", ou seja, sustenta o que-dizer rosiano, funda-lhe o universo.

Destarte, a palavra como gênese garante o "círculo do duplo", que, em meio à complexa trama de reminiscências de Riobaldo, man153 Para mais informações sobre o tema abordado acima ver BOFF, Clodovis. Teoria do Método Teológico. Petrópolis: Vozes, 1999. 297-308 \& FORTE, Bruno. Teologia da bistória: Ensaios sobre a revelação, o início e a consumação. Trad. Georges Ignácio Maissiat. São Paulo: Paulus, 1995. pp. 117-125. Lançando mão dos estudos de H. G. Gadamer, Forte reapresenta os conceitos de linguagem instrumentalista (concepção platônica), reveladora (doutrina cristã do Verbo) e constitutiva (a partir de Humboldt e a filosofia moderna), destacando que é somente na linguagem reveladora que se escapa dos idealismos e niilismos, salvaguardando a verdadeira identidade na diversidade da relação entre palavra e coisa, nas palavras de Forte, "somente se a linguagem proferir a coisa sem esgotá-la é que o Verbo eterno poderá se proferir na carne sem se reduzir a ela”. 
tém a vida em permanente movimento. $\mathrm{O}$ "Deus rosiano" não foge a essa proposta, não é possível vê-lo como uma figura estática e passiva, antes sim em atividade constante (MACHADO, 1991. p. 26). Tão movente como a vida humana, uma vez que "a vida da gente faz sete voltas" (ROSA, 2001. p. 171).

\section{A estória acabada que se continua a contar: Aponta- mentos sobre a ambigüidade da linguagem rosiana}

Esse processual da palavra, no plano da linguagem rosiana foi indicado por Riedel de maneira pontual, assim ela afirma:

O ritmo da narrativa do sertanejo, mais do que o de um personagem-narrador que narrado vivido, é o ritmo de um narrador-personagem que vive o narrado, numa situação existencial que permanece. A narrativa não fala do passado, mas da maneira como esse passado é pensado no presente, quando passa a ser vivido na sua plenitude. Só então o que passou se torna entendido, embora continue questionável. (RIEDEL, 1980. p. 16)

O que a autora nos sinaliza é um método interpretativo (a maneira como Riobaldo entende/lê o vivido), o qual não se descola da linguagem (a maneira como Riobaldo expressa/fala o vivido). Nessa perspectiva, imagem de Deus não poderia deixar de ser ambígua, pois, se a imagem compõe a palavra, dando a ela não somente forma, mas conteúdo, de igual modo a palavra nomeia e, portanto, cria imagens (MAGALHÃES, 2003. p. 82).

O que isso nos ensina? Pode-se dizer, com isso, que entre a imagem e a palavra constrói-se o ser, que, na reflexão riobaldiana, "é e não é” (RIVEIRA, 2005. pp. 81 e 82). É por essa razão que, mesmo declarando o fim da estória...

E aquela era a hora do mais tarde. O céu vem abaixando. Narrei ao senhor. No que narrei, o senhor talvez até ache mais do que a minha verdade. Fim que foi. Aqui a estória se acabou. Aqui, a estória acabada. Aqui a estória acaba. (ROSA, 2001. p. 616)

... Continua a estória ${ }^{154}$. Caso observemos que, após as declara154 Por mais oito páginas Riobaldo rememora seus feitos. 
ções de fim tem-se um ponto, o que temos, na verdade, são três pontos, isto faz com que Riobaldo-velho acabe a estória com uma reticência. Um sinal de "não-encerramento". Um sinal que nos possibilita continuar o vivido por meio do narrado, ou melhor, a estória da vida se prolonga com as plurais possibilidades que a ressignificação e o recontar da vida nos apresentam. O que há, desta maneira, é uma estória in-acaba, assim como é a vida. Deste modo, o interlocutor e o leitor rosiano podem descobrir outras veredas tão verdadeiras quanto as verdades do Riobaldo-velho. A verdade se descortina como virtude a ser descoberta em cada instante da vida. A verdade não é e nem se esgota em si, como o postulado teológico sobre o Deus da Verdade e a Verdade de Deus. A verdade é provisória e se performa na linguagem humana (p. ex.: nas estórias do Riobaldo-estoriador), o que evoca muito mais à verdade na poesia e na mística, do que à verdade na especulação dogmática e filosófica. Páginas antes o protagonista-narrador ratificara essa intuição ao dizer:

(...) o que queria e o que não queria, estória sem final. $O$ correr da vida embrulha tudo, a vida é assim: esquenta e esfria, aperta e daí afrouxa, sossega e depois desinquieta. O que ela quer da gente é coragem. O que Deus quer é ver a gente aprendendo a ser capaz de ficar alegre a mais, no meio da alegria, e inda mais alegre ainda no meio da tristeza! Só assim de repente, na horinha em que se quer de propósito - por coragem. Será? Era o que eu às vezes achava. Ao clarear do dia. (ROSA, 2001. p. 334, negrito meu)

"Ao clarear do dia", a luz necessária para o viver. O sol que ilumina o caminho, o constante já e o perene para-além apontam para o não-encerramento, o qual só é possível na construção literária de Guimarães Rosa com a preservação da ambigüidade ("o que queria e o que não queria" e "vida que esquenta e esfria"), uma vez que esta salvaguarda a provisoriedade do viver e do como expressar na linguagem o vivido. A ambigüidade como traço radical, que caracteriza a linguagem teológica, já não faz parte dos postulados dogmáticos do saber teológico. Em outras palavras, para a construção dos pilares doutrinais da teologia cristã, o pressuposto basilar de sua linguagem foi, de certa forma, banido. 


\section{Escute meu coração, pegue no meu pulso: pistas para uma conclusão}

Ao observarmos que, na escritura rosiana, a conferência simbólica e imagética referente a Deus não deseja ser lida pelo viés do determinado, antes sim, pelo emblema da duplicidade do ser" ${ }^{155}$ - "tudo é e não é" -, aprendemos com a literatura sobre a premência de acolher os extremos no processo narrativo. Isto funda a teia da existência literária. Em outras palavras, posso indicar que, num primeiro momento, teologia e literatura estão lado a lado, suas linguagens acolhem os extremos $\mathrm{e}$ as realidades ambíguas, todavia, com respeito ao universo nascente e seus caminhos/métodos organizacionais, teologia e literatura (a rosiana) se distanciam abruptamente. Uma vez que, a teologia não assume a ambigüidade divina, depurando-a por meio dos processos dogmáticos, enquanto as imagens do "Deus rosiano" são ambíguas e marcam decisivamente o que-dizer rosiano acerca do universo, aquele sertanejouniversal.

O que se refletiu aqui não se refere ao interminável debate sobre a existência ou inexistência de Deus, mas sim como esse Deus, concebido no imaginário teológico, é apresentado no texto rosiano. Ao discutirmos as imagens de Deus, assumimos radicalmente que, assim como disse Riobaldo,

(...) Deus existe, sim, devagarinho, depressa. Ele existe - mas quase só por intermédio da ação das pessoas: de bons e maus. Coisas imensas no mundo. O grande-sertão é a forte arma. Deus é um gatilho? (ROSA, 2001. p. 359)

Quando o "Deus rosiano" aparece, ele se refere sempre às realidades humanas, quanto mais aquelas necessitadas de ressignificação ou de reinvenção de realidade (Riobaldo-velho e sua anamnesis). Em Grande Sertão: Veredas um dito se faz bandeira:

155 O que em muito lembra a contribuição de Paul Tillich sobre o fundamento do ser (Ground of being), o qual pode ser interpretado como chão e fundamento, portanto avesso à ambigüidade (por ser não-simbólico), ou ainda por abismo, o que indicaria o ser sem fundo ou ainda a multiplicidade de possibilidades do ser. Toda essa discussão pode ser aprofundada em: PIRES, Frederico P. A dança do símbolo no cenário da hermenêutica. In: HIGUET, Etienne A. \& MARASCHIN, Jaci. A Forma da Religião: Leituras de Paul Tillich no Brasil. São Bernardo do Campo: Universidade Metodista de São Paulo, 2006. Pp. 27-43. 
O senhor escute meu coração, pegue no meu pulso. O senhor avista meus cabelos brancos... Viver - não é? - é muito perigoso. Porque ainda não se sabe. Porque aprender a viver é que é viver mesmo. (ROSA, 2001. p. 387)

O que há na tentativa rosiana de interpretação do universo humano não tem a ver com a transformação dos conteúdos culturais, numa espécie de programa "conhecer para transformar". Antes sim, seu caminho hermenêutico busca transpor o binário pergunta-resposta (resposta abarcadora do todo real) e revela o estado por vezes agônico em que a linguagem transmite o vivido, nas palavras de Bosi, o mundo narrável. $\mathrm{O}$ que Riobaldo tentou nos ensinar é que não se pode abrir mão das constelações de imagens e símbolos que matizam o universo humano, nem mesmo pode-se abrir mão deste postulado quando a imago Dei está em questão. 


\section{Referências}

ARAUJO, Heloisa Vilhena de. O Roteiro de Deus: Dois estudos sobre Guimarães Rosa. São Paulo: Mandarim, 1996, 556 p.

Bíblia Tradução Ecumênica. São Paulo: Edições Loyola, 1994, 2487 p.

BIZZARRI, Edoardo \& ROSA, João Guimarães. João Guimarães Rosa: Correspondências com seu tradutor italiano Edoardo Bizzarri. Rio de Janeiro: Nova Fronteira, 2003, 207 p.

BUSSOLOTTI, Maria Aparecida F. Marcondes (org.). João Guimarães Rosa: Correspondência com seu tradutor alemão Curt Meyer-Clason. Rio de Janeiro: Nova Fronteira, 2003, p. 238.

BOFF, Clodovis. Teoria do Método Teológico. Petrópolis: Vozes, 1999, $758 \mathrm{p}$.

FORTE, Bruno. Teologia da história: Ensaios sobre a revelação, o início e a consumação. Trad. Georges Ignácio Maissiat. São Paulo: Paulus, 1995, $382 \mathrm{p}$.

GALVÃO, Walnice Nogueira. As formas do falso: Um estudo sobre a ambigüidade no Grande Sertão: Veredas. 2a ed.. São Paulo: Perspectiva, 1986, $132 \mathrm{p}$.

GALVÃO, Walnice Nogueira. Guimarães Rosa. São Paulo: Publifolha, 2000, 77 p.

MACHADO, Ana Maria. Recado do Nome: Leitura de Guimarães Rosa à luz do nome de seus personagens. São Paulo: Martins Fontes, 1991, $146 \mathrm{p}$.

MAGalHãeS, Antonio. Deus no Espelho das Palavras: Teologia e Literatura em diálogo. São Paulo: Paulinas, 2000, 216 p. Série: Literatura e Religião.

MAGALHÃES, Antonio e outros. Teologia e Literatura. São Bernardo 
do Campo: UMESP, 1997, 160 p. Série: Cadernos de Pós-Graduação/ Ciências da Religião 9.

MAGALHÃES, Antonio. Representações do bem e do mal em perspectiva teológico-literária: Reflexões a partir de diálogo com Grande Sertão: Veredas de João Guimarães Rosa. In: V.V.A.A. Estudos da Religião. São Bernardo do Campo: UMESP, 2003. Ano XVII, no 24. 81-96 p.

MANZATTO, Antonio. Teologia e Literatura: Reflexão teológica a partir da antropologia contida nos romances de Jorge Amado. São Paulo: Loyola, 1994, 387 p.

MARTINS, Nilce Sant'Anna. O léxico de Guimarães Rosa. São Paulo: Editora da Universidade de São Paulo, 2001, 537 p.

MILES, Jack. Deus: uma biografia. Trad. José Rubens Siqueira. São Paulo: Companhia das Letras, 1997, 497 p.

RIEDEL, Dirce Côrtes. Meias-Verdades no romance. Rio de Janeiro: Achiamé, 1980. Série: Universidade 10, 130 p.

RIVEIRA, Tânia. Guimarães Rosa e a Psicanálise: Ensaios Sobre imagem e escrita. Rio de Janeiro: Jorge Zahar, 2005, 103 p.

ROSA, João Guimarães. Grande Sertão: Veredas. 19a edição. Rio de Janeiro: Nova Fronteira, 2001, 624 p.

ROSENFIELD, Kathrin Holzermayr. Grande Sertão: Veredas: Roteiro Leitura. São Paulo: Ática, 1992, 111 p. 